\title{
Is Wal-Mart a Bad Neighbor? Repeat Sales Evidence on How Residential Property Values React to a New Big-Box Store
}

\author{
Daniel K. N. Johnson, Kristina Acri née Lybecker \\ Department of Economics and Business, Colorado College, Colorado Springs, USA \\ Email:djohnson@coloradocollege.edu
}

How to cite this paper: Johnson, D.K.N. and née Lybecker, K.A. (2018) Is Wal-Mart a Bad Neighbor? Repeat Sales Evidence on How Residential Property Values React to a New Big-Box Store. Open Journal of Social Sciences, 6, 15-32.

https://doi.org/10.4236/jss.2018.68002

Received: May 31, 2018

Accepted: July 30, 2018

Published: August 2, 2018

Copyright (c) 2018 by authors and Scientific Research Publishing Inc. This work is licensed under the Creative Commons Attribution International License (CC BY 4.0). http://creativecommons.org/licenses/by/4.0/

\begin{abstract}
While there is anecdotal evidence that home values decline when a big-box store, such as Wal-Mart, decides to locate in the area, there is little empirical evidence of that effect. This paper uses a repeat sales model to measure the impact that an arrival has by comparing residential property values, and the speed of sale of the property. Results demonstrate that there is a "news effect" surrounding the arrival, and that the total effect is small, on both property resale value and the number of days that a property spends on the market prior to sale. That impact depends on the type of store, but in the worst-case scenario, the arrival of a big box store is associated with a decline equal in size to mistiming the market by a year. Interestingly, all impacts improve with time, so that even the worst impacts are completely eliminated shortly after a store opening, and the long-run impact on property values is unambiguously positive. So Wal-Mart is quite the opposite of a bad neighbor, if the resident can be patient for the long-term effect.
\end{abstract}

\section{Keywords}

Externality, Location, Real Estate, Residential, Retail

\section{Introduction}

Critics claim that Wal-Mart is bad for local economies, that the stores bankrupt mom-and-pop businesses and drive down property values [1]. Accordingly, recent Wal-Mart openings have generated large public demonstrations against the company's presence in the community and the damaging effects they assert the stores propagate [2] [3]. It is plausible that the presence of big-box stores brings an undesirable quality to the neighborhood, in the form of light/noise pollution 
or congestion, but it is also plausible that a big-box store brings opportunity to the neighborhood in the form of employment or retail convenience, so that the sign of the net impact is inherently ambiguous. Despite the measurability of this effect, very little work has been done by economists to empirically relate Wal-Mart locations to residential property values.

This study uses a repeat sales model to evaluate this claim and analyze the impact of new big-box stores on home prices. We evaluate the spatial correlation between big-box store locations and residential property values, controlling for important aspects of a home's market value such as square footage and age, but also control for immeasurable neighborhood-level effects using information on local school districts and sales price trends within the half-mile-radius neighborhoods. More than that, this study attempts to isolate several distinct impacts of the arrival of a big-box store: the impact of distance to big-box stores and a specific property's sale price, and the impact on a property's time-on-market, estimated simultaneously; a comparison of homes that experienced a new big-box store nearby to homes that did not (via a difference-in-difference analysis); a comparison of several distinct varieties of big-box store to distinguish differential effects; and the importance of time-since-arrival on a property's sale price.

In section II of the paper, we review the literature on property valuation and the spatial impact of construction events. Section III describes the data set. Section IV explains the model utilized and Section V present the regression analyses using several measures of distance to capture the impact of a newly opened store. The final section concludes with interpretation of the results and implications for policy and further research.

\section{Literature}

There is an extensive literature on the effects of big-box stores (and of Wal-Mart in particular) on the economic landscape. A cluster of papers [4]-[9] review and estimate the impact of Wal-Mart on local food store sales, employment, and food distribution networks. Consumer welfare and poverty impacts are estimated by another suite of papers [11] [12].

However, the specific importance of big box stores (defined as retail spaces exceeding 50,000 square feet and serving a wide range of products) to residential housing prices is a topic that remains largely unexplored. New Wal-Mart locations have a depressing effect on local tax revenues in the year after opening, an effect which reverses in the second year [13]. In contrast, there is no evidence that the big box retailer has an impact on residential or commercial property values in New Jersey [14]. However, neither of these pieces reflect on property-specific attributes, or the importance of geography and location, focusing instead on the important issue of jurisdiction-wide residential tax bases. Analysis of the impact of distance from a Wal-Mart store on residential property values shows that proximity matters in the year of completion and dissipates thereafter [15]. However, their analysis does not adequately control for neighborhood ef- 
fects (in fact there are no controls for location other than a measure of distance from the store in question), or for property-specific effects (as they use a list of highly correlated characteristics of the property but do not use a repeated sales model to control for potentially omitted quality factors). In contrast, a competing study [16] examines the impact that Wal-Mart has on housing prices, analyzing over one million housing transactions proximate to $159 \mathrm{Wal}$-Marts. Their findings suggest that a new Wal-Mart store increases housing prices for the closest homes by two to three percent, and that the effect dissipates with distance. Our estimation extends this analysis by considering four types of big box stores, while simultaneously estimating the impact on a property's time-on-market.

The existing literature on property valuation is even more expansive and a complete review is clearly beyond the scope of this paper. Of key importance is property zoning, which is essential to a fair comparison across properties [16]-[21], and thus we focus exclusively on single-family residential properties. As such, the variables discussed here reflect the factors that best explain home prices. The literature unarguably concludes that greater area (acreage) and square footage are clearly associated with higher property valuations [22] [23] [24] [25] [26]. Highly correlated with these measures are home characteristics such as the number of bedrooms [27] and bathrooms [25] [26], both of which are unambiguously associated with higher property values.

The date of sale is clearly important, whether directly [27] [28] or indirectly via standardization against assessed or neighborhood averages as they change over time [29] [30]. Frequently, analysis will include indicator variables for each date of repeated sales on a property, to avoid the inherent problems of choosing a deflation index. In addition, the time since construction (age of the property) at the date of sale is also frequently included, often in a nonlinear way to represent consumer preferences for historic homes or new construction, relative to middle-aged residences [25] [31].

Several scholars have also explored the relationship between price and patience. As such this analysis considers both sale price and current days on market (or time-on-market). Sellers balance two distinct objectives: to sell their properties at the highest possible price and to make the sale quickly. Earlier work has shown that the seller faces a tradeoff between the time it takes to sell the home and the price received. Specifically, an overly high initial price may discourage potential buyers and result in a home languishing on the market for a longer period of time, while an initial price that is too low may result in a quick sale at a price less than could have been received. Research shows that sellers with lower home equity have a tendency to elect a higher list price and wait a longer period of time to sell the property [32]. A more recent study finds that the degree of overpricing (percentage difference between actual and expected list prices) increases a home's expected time on the market [33]. During periods of falling home prices, sellers may hold sticky reservation prices which results in 
properties spending more time on the market [34]. Finally, a 2008 study on the Dutch housing market [35] shows that atypical houses are more difficult to price and therefore spend more time on the market before price revisions.

In addition, studies have clearly shown that proximity to landmark neighborhood institutions has an effect on proximate property values. These have been calculated for desirable institutions such as parks [36] [37] but are most often calculated for potentially negative pollution effects and health risks from transportation or energy sector installations [38] [39] [40]. At the extreme, there is a branch of the literature that examines the housing price responses to hazardous waste locations or Superfund sites [41] [42] [43] [44]. Occasionally, analysis focuses on the impact of an institution with potential for either positive or negative impact, such as a sports stadium [45]. In this vein of the literature, there is also some evidence that residential proximity to differently zoned communities (e.g. mixed use or commercial) impacts residential property values as well [18] [19] [20] [21].

Repeated sales models rely on a subset of observations for properties which have been valued more than once, therefore abstracting away from the hedonic treatment of property characteristics as an implicit fixed effect of the property in order to focus on changes in valuation over time [44] [46] [47]. We aim to follow in this tradition, including controls for neighborhood-specific as well, to avoid any spatial bias.

\section{Data Description}

This study focuses on single-family home sales within a two-mile radius of 13 big-box stores in El Paso County, Colorado between 1994 and 2005 from a limited-term collaborative data sharing arrangement with the County Assessor's Office and a local realtor. The stores include five Wal-Mart stores, two Best Buy stores, three Kmart stores, and three Target stores. The study focuses only on repeat sales that span the opening of a Wal-Mart or a Best Buy stores, using the Kmart stores (whose construction all predate our study period), and all of the Target stores (whose construction all fall at the very end of our study period) as controls to reflect the potential big-box nature of a neighborhood, whether or not a Wal-Mart or Best Buy decides to locate in that area.

The opening dates for the 13 big-box stores located within the city of Colorado Springs, Colorado were collected from the El Paso County Planning Department and confirmed with the national headquarters of the retail chains and local phonebooks. The opening dates were used to determine how many open big-box stores were within a two-mile radius of each property at the time of each sale and which homes sold both before and after the opening of a big-box store within a two-mile radius. Finally, the opening dates were used to calculate the number of days between the opening of the store and the date of sale of the property for the newest big-box store located within the property's two-mile radius. 
Data were gathered from the Pikes Peak Multiple Listing Service (MLS) on every single-family property sold in El Paso County, Colorado between January 1, 1994 and December 31, 2005. ${ }^{1}$ For each property, we obtained the address, total square feet, year built, sales price, and current days on market before sale. Of the 102,017 recorded sales, 11,962 properties were sold multiple times during the period, and 1660 of these sales are characterized by the opening of a big-box store in the period between the two sales.

While data were collected on the number of bedrooms, bathrooms and total square footage, these variables were highly correlated, so the study utilizes only total square footage and the change in total square footage (area added between the first and second sales). This is not a trivial correction, given that many properties in our sample date from the late 1800s when large numbers of bedrooms and bathrooms were less common, even in expansive homes, but have been expanded over time.

Using GIS mapping software, we measured the distances (measured in feet) from each property to every big-box store located within a two-mile radius. ${ }^{2}$ We also identified the corresponding El Paso county school district for each property.

Table 1 contains a description of the variables used in the study. Beyond control variables for the age and size of the property, we include distance as a set of categorical dummy variables in order to provide for the most possible flexibility in the estimated functional form. Specifically, we account for distance in both $1 / 10^{\text {th }}$ and half-mile increments within a two-mile radius surrounding a new store. In addition to the distance dummy variables, we include dummies for the year of first sale, the year of second sale, and the Colorado Springs school district in which the property is located.

On average, properties sold for a little more than one-quarter more on their second sale, an average price increase of roughly $\$ 33,000$ (over an inter-sale time difference that averaged 1398 days or roughly three and three-quarter years in our sample). While the range in sales prices seems very wide, it is in fact due to only a few outliers. Less than 300 properties (two percent of the sample) increased in price by more than $\$ 100,000$ between repeat sales. Those outliers are accommodated using square footage at the time of each sale (i.e. they all involve a dramatic increase in square footage).

Properties in our sample are fairly standard for North America, averaging 1979 square feet, and ranging from 790 to 10,417 square feet. The average home was a little over 27 years old at the time of sale, but our sample includes new constructions and some properties over a century old. Properties averaged 45 days on the market, but again the variance was large, with 484 selling on the

${ }^{1}$ We are grateful to Nate Banet of Flying Horse Realty, Colorado Springs, for providing us access to the Pikes Peak MLS system. This allowed us to gather the most accurate and complete data set available. These data were gathered between June 22 and June 26, 2009.

${ }^{2}$ We are grateful to Stephen Fischer, the GIS Database Coordinator for the Assessor's Office of El Paso County, Colorado for providing these calculations. 
Table 1. Description of variables and summary statistics.

\begin{tabular}{|c|c|c|c|c|c|c|c|c|c|}
\hline \multirow{2}{*}{ Variable } & \multirow{2}{*}{$\begin{array}{c}\text { Description } \\
\text { (units of measurement) }\end{array}$} & \multicolumn{4}{|c|}{ Complete Sample } & \multicolumn{4}{|c|}{ Sample of Affected Homes } \\
\hline & & Mean & St. Dev. & Min. & Max. & Mean & St. Dev. & Min. & Max. \\
\hline$\% \Delta$ saleprice & $\begin{array}{l}\text { Difference between second and first } \\
\text { sale price (\$) }\end{array}$ & 26.57 & 28.17 & -89.90 & 1175.02 & 29.61 & 24.16 & -87.94 & 213.92 \\
\hline cdom & Days on market at second sale & 44.96 & 56.29 & 0 & 1297 & 43.14 & 50.29 & 0 & 491 \\
\hline Sqft & $\begin{array}{l}\text { Total square footage of property ( } \mathrm{ft} \text { ) } \\
\text { as of the date of the second sale }\end{array}$ & 1979.13 & 789.30 & 500 & 10,417 & 1987.64 & 688.22 & 654 & 8520 \\
\hline Additionalsqft & $\begin{array}{l}\text { Change in square footage of property } \\
\text { between first and second sales }\end{array}$ & 33.13 & 133.73 & 0 & 4715 & 28.39 & 124.12 & 0 & 3771 \\
\hline Age & $\begin{array}{l}\text { Age of property at time of sale (years) } \\
\text { as of the date of the second sale }\end{array}$ & 27.25 & 24.35 & 0 & 129 & 18.45 & 15.79 & 0 & 106 \\
\hline Distance & $\begin{array}{l}\text { Distance to the nearest big-box store } \\
\text { at the date of second sale }\end{array}$ & 6650.34 & 2530.62 & 538.78 & $11,205.25$ & 5391.60 & 2228.16 & 631.63 & $10,670.75$ \\
\hline Dayssincenew & $\begin{array}{c}\text { Number of days between the opening } \\
\text { of the newest Big-box store and the } \\
\text { date of second sale (days) }\end{array}$ & 2365.88 & 975.95 & 0 & 3745 & 2724.97 & 984.44 & 12 & 3745 \\
\hline
\end{tabular}

same day they were listed but one spending 3.5 years on the market before selling.

Most interestingly, we find that properties that experienced a new big-box store are quite average, except that they are on average one-third younger than the full sample, and are a little less prone to improvement in square footage during the inter-sale period.

Figure 1 shows the distribution of properties around big-box stores, grouped into categories spanning one tenth of a mile (e.g. less than 0.1 miles to the new Wal-Mart, 0.1 or more miles but less than 0.2 miles to the new Wal-Mart). Table 2 further compares three groups of properties: those that experience a new Wal-Mart between sales, those that welcome a new Best Buy between sales, and the control group that experiences no new big-box stores between sales. The control group is somewhat more evenly distributed spatially than either treatment group, and there is an unusual spike in the Best Buy distribution due to the placement of one particular new Best Buy. This gives the control group a larger average distance from big-box stores than the treatment group (averaging 6774.88 feet from a store, versus 5417.25 feet and 5328.11 feet for Wal-Mart and Best Buy groups respectively), but there are still plenty of property sales to use for comparison in the control group once distance is included as a variable in the analysis below.

Although our analysis includes a year dummy which should capture the annual macroeconomic variables impacting sample properties (including residentially-based inflation), and we use repeated sales explicitly in order to capture immeasurable property-specific attributes (such as view or landscaping), we are still concerned about neighborhood-level effects. For that reason, we include indicator variables for the school district, and also construct a time-varying neighborhood average sales price which trails each sale by one year. The prior year's average sales price of all homes within one half-mile of the selling 


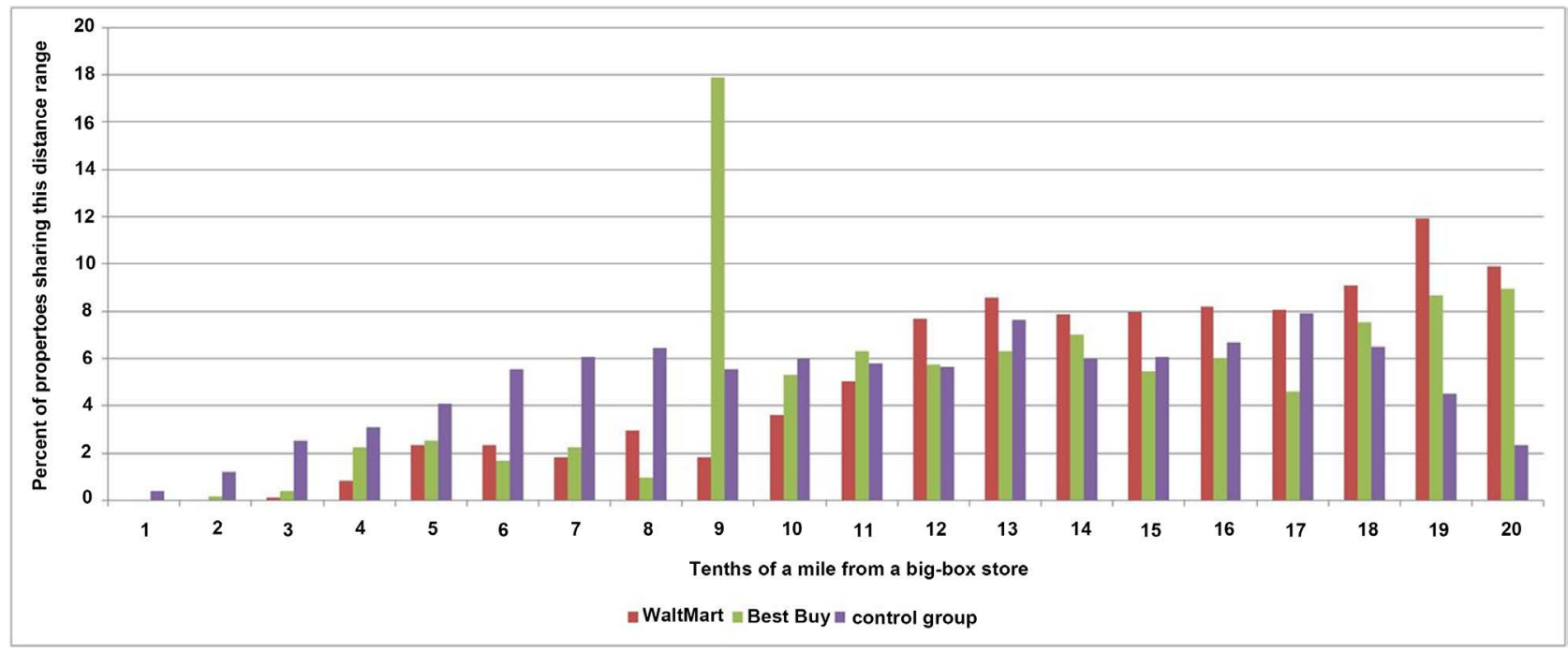

Figure 1. Proximity of homes to a new big-box store.

Table 2. Average home sales price by big box store (2-mile radius) \& average home sales price and age (in years) by big box brand, 1994-2005.

\begin{tabular}{llllllllllllll}
\hline & 1994 & 1995 & 1996 & 1997 & 1998 & 1999 & 2000 & 2001 & 2002 & 2003 & 2004 & 2005 \\
\hline Sales Price & & & & & & &
\end{tabular}

CS Average $\$ 105,083.00 \$ 114,160.50 \quad \$ 120,122.20 \quad \$ 128,917.70 \quad \$ 134,272.60 \quad \$ 144,232.50 \quad \$ 156,253.70 \quad \$ 167,207.40 \quad \$ 179,292.80 \quad \$ 174,041.90 \quad \$ 174,567.90 \quad \$ 172,240.90$ Wal-Mart 1

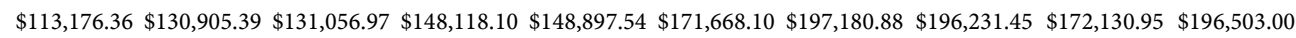

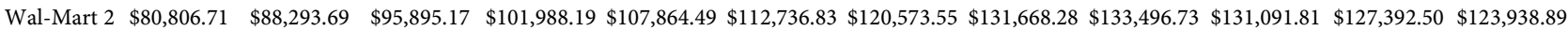
Wal-Mart 3 $\$ 164,180.00 \$ 144,137.63 \$ 142,000.00$ Wal-Mart $4 \$ 188,152.89 \$ 263,047.25 \$ 179,085.60 \quad \$ 219,513.38 \quad \$ 243,096.00 \$ 280,290.75 \$ 348,128.08 \quad \$ 326,242.86 \quad \$ 389,400.00 \quad \$ 486,900.00 \quad \$ 332,000.00$ Wal-Mart 5

Kmart $1 \quad \$ 106,896.07 \$ 112,461.84 \$ 129,701.96 \quad \$ 127,301.88 \quad \$ 134,265.29 \quad \$ 155,659.52 \quad \$ 157,899.08 \quad \$ 159,296.81 \quad \$ 191,218.67 \quad \$ 166,112.91 \quad \$ 181,810.30 \quad \$ 188,300.00$ Kmart $2 \quad \$ 105,003.70 \$ 110,972.39 \$ 116,617.11 \quad \$ 123,343.50 \quad \$ 124,800.18 \quad \$ 133,707.48 \quad \$ 141,307.48 \quad \$ 154,759.18 \quad \$ 158,800.90 \quad \$ 157,244.81 \quad \$ 154,217.86 \quad \$ 133,187.00$

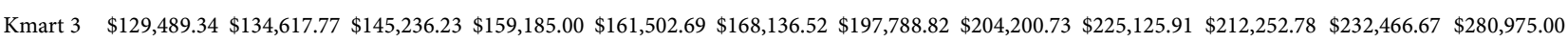

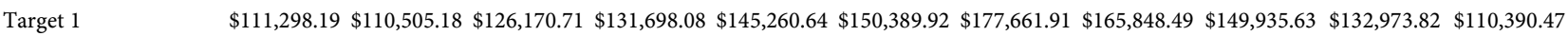

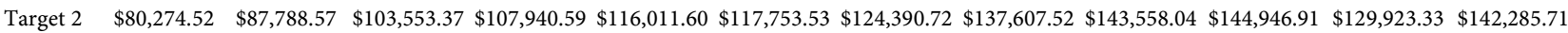
Target $3 \quad \$ 117,455.89 \$ 129,104.98 \quad \$ 130,729.20 \quad \$ 140,526.39 \$ 145,081.79 \$ 158,678.03 \quad \$ 171,276.24 \quad \$ 186,950.68 \quad \$ 191,173.18 \quad \$ 185,997.47 \quad \$ 170,562.50 \quad \$ 183,854.44$ Best Buy 1 $\$ 195,044.50 \$ 175,302.88$ Best Buy $2 \quad \$ 168,260.71 \$ 152,121.10 \$ 159,475.00 \$ 168,739.36 \$ 175,760.81 \quad \$ 177,699.92 \quad \$ 189,345.24 \$ 225,976.92 \quad \$ 206,325.00 \quad \$ 243,732.22 \quad \$ 239,000.00$

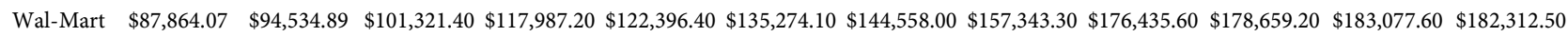
Kmart $\quad \$ 111,666.60 \$ 118,454.20 \$ 127,348.20 \$ 133,582.60 \$ 136,946.00 \quad \$ 147,658.20 \quad \$ 161,978.80 \quad \$ 168,644.00 \quad \$ 183,900.10 \quad \$ 177,603.60 \quad \$ 183,919.80 \quad \$ 200,380.10$ Target $\quad \$ 105,226.30 \$ 115,536.70 \$ 117,997.70 \quad \$ 128,182.10 \quad \$ 134,754.80 \quad \$ 144,132.50 \quad \$ 155,795.90 \$ 171,606.10 \quad \$ 173,215.00 \quad \$ 162,541.30 \quad \$ 146,586.50 \quad \$ 138,920.90$ Best Buy $\quad \$ 168,260.70 \$ 152,121.10 \quad \$ 159,475.00 \quad \$ 168,739.40 \quad \$ 175,760.80 \quad \$ 177,699.90 \quad \$ 189,345.20 \quad \$ 225,976.90 \quad \$ 206,325.00 \quad \$ 234,879.90 \quad \$ 182,380.30$

\begin{tabular}{|c|c|c|c|c|c|c|c|c|c|c|c|c|}
\hline \multicolumn{13}{|l|}{ Home Age } \\
\hline CS Average & 23.2 & 21.9 & 24.6 & 27.4 & 26.9 & 29.2 & 30.3 & 31.1 & 32.2 & 34.1 & 32.4 & 39.9 \\
\hline Wal-Mart & 38.9 & 38.1 & 44.5 & 50.9 & 52.0 & 52.0 & 54.7 & 56.3 & 56.5 & 46.9 & 35.9 & 41.6 \\
\hline Kmart & 21.1 & 20.3 & 23.8 & 23.5 & 22.6 & 24.6 & 24.6 & 24.6 & 26.3 & 31.0 & 30.5 & 38.3 \\
\hline Target & 16.5 & 16.9 & 18.0 & 17.3 & 18.3 & 19.6 & 21.4 & 20.1 & 22.2 & 24.2 & 29.6 & 35.7 \\
\hline Best Buy & & 17.2 & 17.9 & 14.9 & 20.2 & 19.1 & 22.0 & 19.1 & 25.3 & 25.9 & 25.0 & 16.9 \\
\hline
\end{tabular}


property, that is equally distant to the nearest big-box store, aims to capture the trend of the area. For example, it is critical to ascertain whether big-box stores are entering lower-priced neighborhoods or whether they cause lower-priced neighborhoods.

We approach this concern in two additional ways. First, we employ a difference-in-difference approach in our estimation model, comparing homes that experienced a big-box store arrival against similarly located properties (i.e., elsewhere in the city, equidistant from pre-existing big-box stores) which did not experience a new big-box arrival. We emulate previous literature [48] [49] in this regard, both of which use the technique to estimate the impact of environmental enhancements on residential property values in an urban setting. While we would prefer to use a spatial spline or spatial regression model, computational limitations prevented that approach with our number of observations, and we were reluctant to resort to sampling tactics.

Second, we explore the data here for pre-existing differences between "Wal-Mart neighborhoods" and "Best Buy neighborhoods". Table 2 presents sales price and property age information for each circle surrounding the 13 stores in our sample, and summarizes those by brand of retailer. Notice that home values peak in price around 2002 citywide, but some regions peak considerably later (e.g. Best Buy 2 peaks in 2004). Of course, each region has a specific neighborhood character which contributes to level effects in prices as well; the Wal-Mart 4 region is frequently twice the citywide average price while the Wal-Mart 2 zone lags the average by ten percent or more.

Notice also in Table 2 that the neighborhoods in which stores situate can differ greatly by age of the residential properties. Wal-Marts are consistently in older neighborhoods than other stores, although the width of that gap varies by year. This offers strong rationale for including a thoughtful list of control variables in multivariate regression analyses.

Figure 2 and Figure 3 then plot those data for each brand of retailer. In terms of home sales prices, Best Buy stores are located in neighborhoods with higher-than-average home sales prices while Wal-Mart and Target stores seem to be located in neighborhoods with lower-than-average home sales prices. Kmart stores most closely track the average. Unfortunately, while the time trend is informative, it fails to reveal any information about home prices at the time the big box retailer acquired the land or even started the approval process for the construction of a new store. Figure 3 reveals that Wal-Mart stores are located in more established neighborhoods with older-than-average homes while the other three retailers, Best Buy, Target and Kmart, tend to locate in newer neighborhoods. It is interesting to note that Best Buy appears to be located in newer neighborhoods (Figure 3), but with more expensive homes (Figure 2).

\section{Model and Estimation}

There is clearly an issue of mutual endogeneity when considering sales price and time-on-market (as pointed out by [33] [35] [50] [51]), so we estimate the 


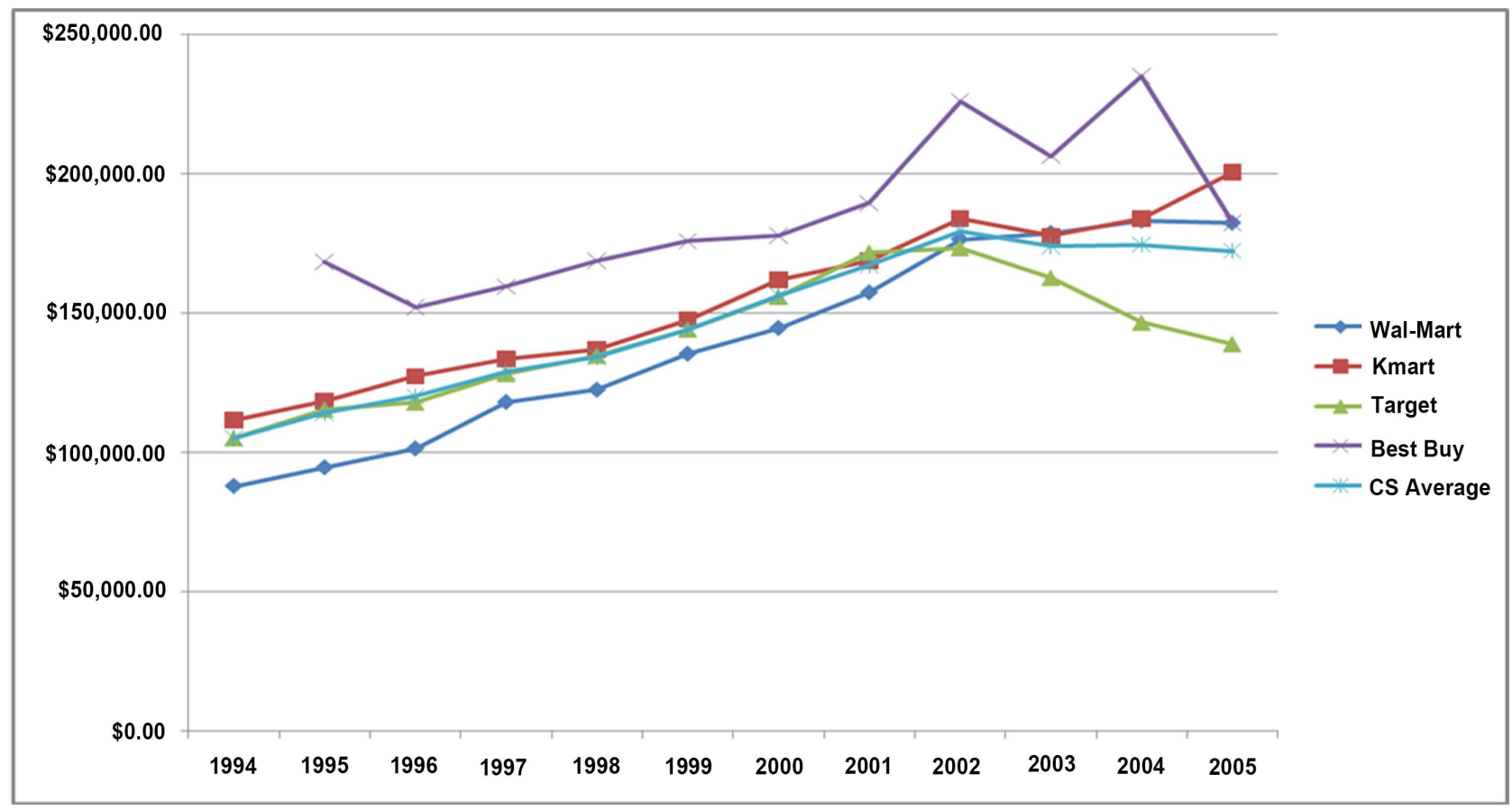

Figure 2. Average home sale price within 2-mile radius of big box brand, 1994-2005.

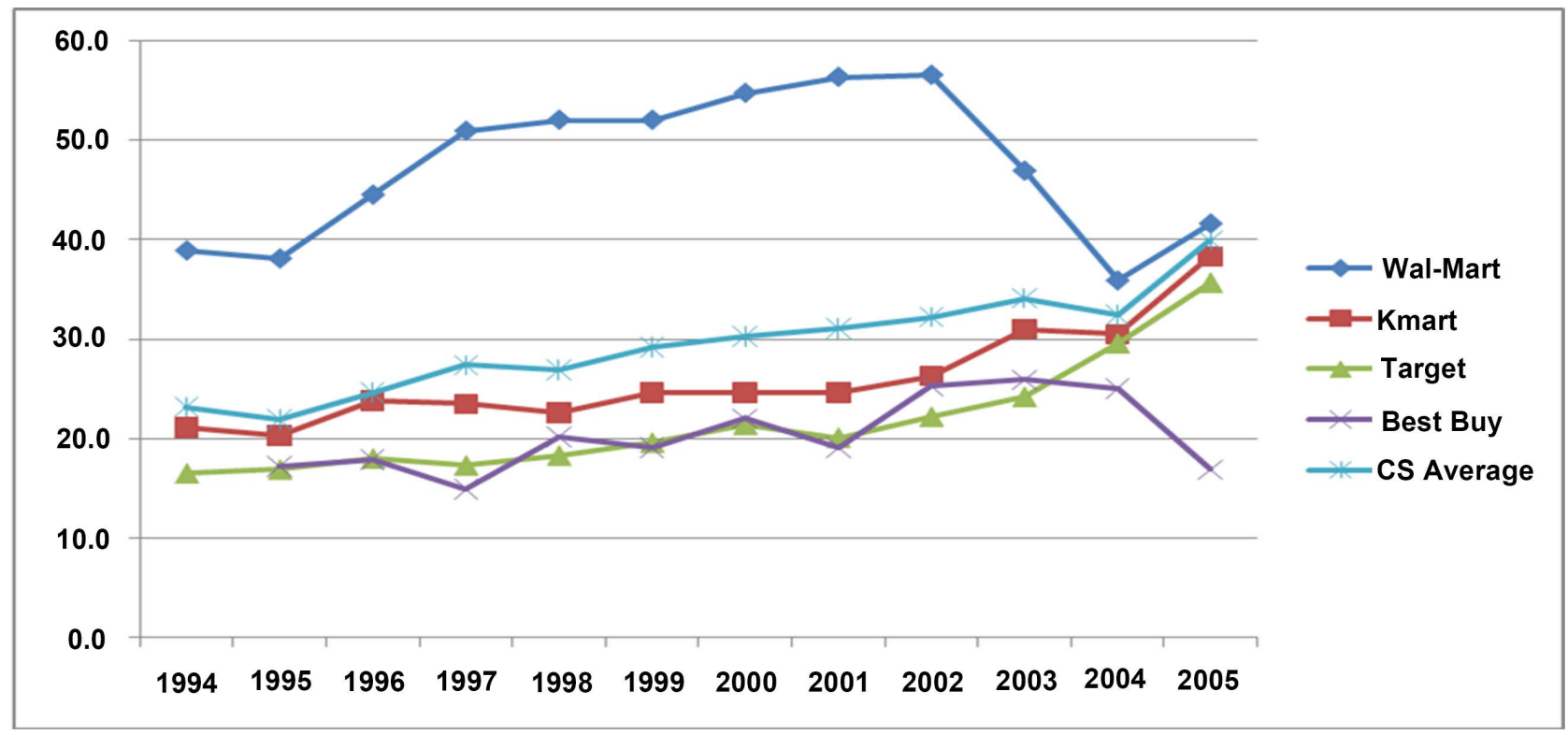

Figure 3. Average home age (in years) within 2-mile radius of big box brand, 1994-2005.

following two-equation system using Two-Stage Least Squares (2SLS) to instrument for price in the time-on-market equation (a variation of the approach followed by [52]). There is an empirically low correlation between the two variables, at -0.007 , but we instrument to be sure that idiosyncratic effects do not bias our results. Further, we do not assume a well-behaved error distribution, but instead use the methodology described by [53] to weight observations for more efficient estimation. Otherwise, the simple reduced-form structure is 
consistent with the literature's precedents using repeated sales models (e.g. [46]):

$$
\begin{aligned}
& \% \Delta \text { sales price } \\
& =\delta+\beta_{1} \mathrm{sqft}+\beta_{2} \text { addedsqft }+\beta_{3} \text { age }+\beta_{4} \text { age }^{2}+\beta_{5} \text { distance }_{W}+\beta_{6} \text { newstore }_{W} \\
& +\beta_{4} \text { distance }_{W} * \text { newstore }_{W}+\beta_{8} \text { distance }_{B}+\beta_{9} \text { newstore }_{B} \\
& +\beta_{10} \text { distance }_{B} * \text { newstore }_{B}+\beta_{11} \text { dayssincenew } \beta_{12} \text { distance }_{K} \\
& +\beta_{13} \text { distance }_{T}+\sum_{I=1994}^{2005} \alpha_{i} \text { saleyear }_{i}+\sum_{I=1994}^{2005} \mu_{i} \text { resaleyear }_{j} \\
& +\sum_{h=1}^{4} \lambda_{h} \text { district }_{h}+\lambda_{5} \text { areaprice_diff }+\varepsilon \\
& \text { days on market } \\
& =\gamma_{0}+\gamma_{1}(\% \Delta \text { sales price })+\eta_{1} \text { sqft }+\eta_{2} \text { addedsqft }+\eta_{3} \text { age }+\eta_{4} \text { age }^{2} \\
& +\eta_{5} \text { distance }_{W}+\eta_{6} \text { newstore }_{W}+\eta_{7} \text { distance }_{W} * \text { newstore }_{W}+\eta_{8} \text { distance }_{B} \\
& +\eta_{9} \text { newstore }_{B}+\eta_{10} \text { distance }_{B} * \text { newstore }_{B}+\eta_{11} \text { dayssincenew } \\
& +\eta_{12} \text { distance }_{K}+\eta_{13} \text { distance }_{T}+\sum_{i=1994}^{2005} \theta \text { saleyear }_{i}+\sum_{j=1994}^{2005} \vartheta_{j} \text { resaleyear }_{j}
\end{aligned}
$$

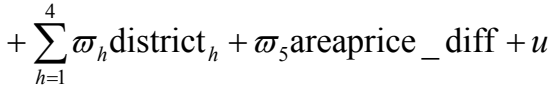

where: $\% \Delta$ in sales price is measured between the first and second sale (appearing in its precise value in the first equation, and following instrumental variable procedure, in estimated form in the second equation);

sqft is the number of square feet, improved or unimproved, encompassed in the residence at the date of first sale;

addedsqft is the change in square footage between the first and second sales; age is the age in years of the residence at time of first sale;

distance $_{W}$ is the distance to the nearest Wal-Mart at the time of first sale;

newstore $_{W}$ is an indicator of whether a new Wal-Mart has opened in the period between sales;

distance $_{B}$ is the distance to the nearest Best Buy at the time of first sale; newstore $_{B}$ is an indicator of whether a new Best Buy has opened in the period between sales;

dayssincenew is the number of days that have elapsed between the opening of a new store and the second sale;

saleyear ${ }_{i}$ is a dummy variable for the year of first sale;

resaleyear ${ }_{j}$ is a dummy variable for the year of second sale;

district $_{h}$ is a dummy variable for each school district;

areaprice_diff is the difference between this property's sale price and the average sale price of all properties within one half-mile of the property in the year prior to the second sale, given that they are equidistant to the nearest big-box store (within one-tenth of a mile);

The dependent variables are percentage change in sales price and 
time-on-market (measured in days) respectively. We do not emulate the literature in using a semi-log functional form simply due to the striking number of negative price changes in the sample.

Notice that we adopt the difference-in-difference approach to compare properties that were equidistant from pre-existing big-box stores (distance ${ }_{W}$ and distance ${ }_{B}$ ), separating them into experiment and control groups by virtue of whether they experienced the arrival of a new Wal-Mart or Best Buy big-box store (newstore ${ }_{W}$ and newstore ${ }_{B}$ ), and including the interaction term to explore the different impacts of location on each group.

\section{Analysis}

Table 3 presents the results of the primary regression, with the percentage change in residential property sales prices and days-on-market respectively. We also tested versions of this specification that included squared distance terms, and versions that included indicator variables for properties that fall into consecutive distance bands (tenth-mile and half-mile). All of those sensitivity tests differ only trivially from the primary results.

Further, we tested whether the possible presence of non-market transactions, or outlier observations showing an abnormally small or abnormally large change in price between sales, might influence our results. Only 83 observations (less than one percent of the sample) are more than 3 standard deviations away from the mean change in sales price, and only 281 (slightly over two percent of the sample) are more than two standard deviations away from the mean. While it is impossible to verify whether any of these might be non-market transactions, omitting all properties beyond two standard deviations had no effect on the implications of the coefficients.

The left columns of Table 3 offer results for all properties in the sample. The right columns provide parallel results for properties which sold four or more times during the sample period, to determine whether these properties might behave differently than other properties. Notice that a pure difference-in-difference approach is not possible for these frequently-resold properties, as less than five percent of those property sales experienced the opening of a new store between sales, leading to multicollinearity problems in estimation of the interaction term. However, the pattern of other coefficients of the difference-in-difference approach leads us to believe that the same results could hold true, if a larger dataset were procured.

Table 3 confirms our expectations regarding control variables. Larger homes appreciate more quickly than their smaller peers, and an increase in square footage naturally increases the selling price of appreciation with a longer period of time between resales, although the size of that appreciation naturally depends on the purchasing and selling years. Neighborhood prices show reversion toward the mean, meaning that homes above the neighborhood average price tend to sell for less than their other characteristics would suggest, and the reverse also holds. 
Table 3. Impact of big-box store locations on residential property sales prices and current days on market.

\begin{tabular}{|c|c|c|c|c|c|c|c|c|c|c|c|c|}
\hline \multirow{3}{*}{8} & \multicolumn{6}{|c|}{ All Properties } & \multicolumn{6}{|c|}{$\begin{array}{c}\text { Properties that Sold } 4 \text { or More } \\
\text { Times During Period }\end{array}$} \\
\hline & \multicolumn{2}{|c|}{$\% \Delta$ in Sales Price } & \multicolumn{4}{|c|}{ Current Days on Market } & \multicolumn{3}{|c|}{$\% \Delta$ in Sales Price } & \multicolumn{3}{|c|}{ Current Days on Market } \\
\hline & coefficient & t-stat & & coefficient & z-stat & & coefficient & t-stat & & coefficient & z-stat & \\
\hline Initial square footage & $2.78 \times 10^{-3}$ & 8.46 & $* * *$ & $1.24 \times 10^{-2}$ & 12.66 & $* * *$ & $3.15 \times 10^{-3}$ & 3.16 & $* * *$ & $1.35 \times 10^{-2}$ & 2.96 & $* * *$ \\
\hline Additional square footage & $1.15 \times 10^{-2}$ & 4.81 & $* * *$ & $2.66 \times 10^{-2}$ & 3.70 & $* * *$ & $1.88 \times 10^{-2}$ & 6.30 & $* * *$ & $4.81 \times 10^{-2}$ & 1.77 & * \\
\hline Age of property & 0.15 & 7.00 & $* * *$ & -0.53 & -4.69 & $* * *$ & $8.31 \times 10^{-2}$ & 1.12 & & 0.25 & 0.51 & \\
\hline Age of property squared & $-2.33 \times 10^{-4}$ & -1.07 & & $5.38 \times 10^{-3}$ & 6.52 & $* * *$ & $5.00 \times 10^{-4}$ & 0.79 & & $3.23 \times 10^{-3}$ & 0.86 & \\
\hline Distance (in feet) to nearest Wal-Mart & $1.06 \times 10^{-4}$ & 0.88 & & $-1.08 \times 10^{-4}$ & -0.26 & & $3.95 \times 10^{-4}$ & 1.82 & * & $1.11 \times 10^{-3}$ & 0.98 & \\
\hline Arrival of new Wal-Mart between sales & 0.90 & 1.96 & ** & -0.70 & -0.43 & & -0.09 & -0.07 & & 0.16 & 0.03 & \\
\hline Distance (in feet) to nearest Best Buy & $8.38 \times 10^{-4}$ & 4.35 & $* * *$ & $1.78 \times 10^{-4}$ & 0.19 & & $2.45 \times 10^{-3}$ & 0.63 & & $-4.30 \times 10^{-2}$ & -2.29 & ** \\
\hline Arrival of new Best Buy between sales & 0.98 & 2.87 & $* * *$ & -3.50 & -1.91 & * & 2.67 & 0.33 & & -2.60 & -0.57 & \\
\hline $\begin{array}{l}\text { Interaction of distance and arrival of } \\
\text { new Best Buy }\end{array}$ & $-2.01 \times 10^{-4}$ & -3.81 & $* * *$ & $9.38 \times 10^{-5}$ & 0.30 & & & & & & & \\
\hline Days since new store opened & $1.26 \times 10^{-2}$ & 9.61 & $* * *$ & $1.15 \times 10^{-3}$ & 0.17 & & $1.51 \times 10^{-2}$ & 3.90 & $* * *$ & $6.36 \times 10^{-2}$ & 2.16 & ** \\
\hline Distance (in feet) to nearest K-Mart & $1.14 \times 10^{-4}$ & 2.53 & ** & $-2.22 \times 10^{-4}$ & -1.00 & & $1.78 \times 10^{-4}$ & 1.10 & & $-4.41 \times 10^{-4}$ & -0.46 & \\
\hline Distance (in feet) to nearest Target & $-3.68 \times 10^{-5}$ & -0.62 & & $3.54 \times 10^{-5}$ & 0.13 & & $-2.66 \times 10^{-5}$ & -0.13 & & $3.61 \times 10^{-4}$ & 0.30 & \\
\hline School District 11 & -2.61 & -6.58 & $* * *$ & -5.41 & -2.68 & $* * *$ & -2.34 & -1.44 & & -7.60 & -0.93 & \\
\hline School District 12 & 6.06 & 6.20 & $* * *$ & -5.68 & -1.39 & & 8.28 & 1.59 & & -4.29 & -0.15 & \\
\hline School District 49 & -2.07 & -3.73 & $* * *$ & -2.29 & -0.76 & & -1.63 & -0.79 & & -0.12 & -0.01 & \\
\hline Initial sale year 1995 & -7.91 & 16.10 & $* * *$ & 7.32 & 2.12 & ** & -10.37 & -5.44 & $* * *$ & -31.10 & -1.72 & * \\
\hline Initial sale year 1996 & -15.84 & -31.20 & $* * *$ & 4.51 & 0.81 & & -18.25 & -9.65 & $* * *$ & -59.56 & -2.20 & ** \\
\hline Initial sale year 1997 & -19.77 & -35.28 & $* * *$ & 8.58 & 1.28 & * & -22.00 & -10.75 & $* * *$ & -60.42 & -1.88 & * \\
\hline Initial sale year 1998 & -24.55 & -43.43 & $* * *$ & 9.78 & 1.20 & & -22.84 & -10.76 & $* * *$ & -55.09 & -1.67 & * \\
\hline Initial sale year 1999 & -30.39 & -50.55 & $* * *$ & 6.45 & 0.64 & & -28.22 & -12.21 & $* * *$ & -79.64 & -2.02 & $* *$ \\
\hline Initial sale year 2000 & -37.33 & -58.61 & $* * *$ & -5.59 & -0.47 & & -35.40 & -15.23 & $* * *$ & -112.74 & -2.34 & ** \\
\hline Initial sale year 2001 & -46.21 & -69.52 & $* * *$ & -16.72 & -1.12 & & -41.53 & -15.91 & $* * *$ & -140.51 & -2.49 & ** \\
\hline Initial sale year 2002 & -49.14 & -65.04 & $* * *$ & -11.87 & -0.76 & & -46.60 & -16.30 & $* * *$ & -140.36 & -2.21 & $* *$ \\
\hline Initial sale year 2003 & -46.98 & -50.34 & $* * *$ & -7.82 & -0.50 & & -44.46 & -14.10 & $* * *$ & -116.74 & -1.92 & * \\
\hline Initial sale year 2004 & -43.83 & -41.17 & $* * *$ & -14.58 & -1.02 & & -37.49 & -9.86 & $* * *$ & -128.38 & -2.45 & ** \\
\hline Initial sale year 2005 & -44.14 & -27.36 & $* * *$ & 7.53 & 0.48 & & -33.73 & -6.30 & $* * *$ & -100.60 & -2.08 & $* *$ \\
\hline Subsequent sale year 1995 & 7.94 & 4.44 & $* * *$ & -23.02 & -1.73 & $* *$ & 6.27 & 1.25 & & -57.59 & -1.71 & * \\
\hline Subsequent sale year 1996 & 10.90 & 6.29 & $* * *$ & -24.92 & -1.88 & $* *$ & 8.98 & 1.81 & * & -52.11 & -1.48 & \\
\hline Subsequent sale year 1997 & 9.51 & 5.11 & $* * *$ & -21.84 & -1.60 & ** & 7.37 & 1.41 & & -53.05 & -1.41 & \\
\hline Subsequent sale year 1998 & 8.84 & 4.16 & $* * *$ & -29.06 & -2.07 & ** & 6.10 & 0.99 & & -75.65 & -1.87 & * \\
\hline Subsequent sale year 1999 & 9.26 & 3.79 & $* * *$ & -22.13 & -1.47 & & 4.09 & 0.58 & & -75.04 & -1.64 & * \\
\hline
\end{tabular}




\begin{tabular}{|c|c|c|c|c|c|c|c|c|c|c|c|c|}
\hline Subsequent sale year 2000 & 11.92 & 4.23 & $* * *$ & -20.47 & -1.27 & & 3.68 & 0.45 & & -88.75 & -1.76 & * \\
\hline Subsequent sale year 2001 & 17.65 & 5.51 & $* * *$ & -20.38 & -1.14 & & 7.76 & 0.84 & & -85.72 & -1.50 & \\
\hline Subsequent sale year 2003 & 14.36 & 3.55 & $* * *$ & -12.19 & -0.60 & & -0.89 & -0.07 & & -118.94 & -1.72 & * \\
\hline Subsequent sale year 2004 & 12.95 & 2.89 & $* * *$ & -16.07 & -0.74 & & -4.28 & -0.32 & & -134.22 & -1.77 & * \\
\hline Subsequent sale year 2005 & 13.20 & 2.69 & $* * *$ & -11.83 & -0.51 & & -4.99 & -0.35 & & -145.58 & -1.74 & * \\
\hline Difference from area average sales price & $-7.76 \times 10^{-5}$ & -12.51 & $* * *$ & --- & --- & & $-8.78 \times 10^{-5}$ & -5.27 & $* * *$ & --- & --- & \\
\hline Constant & -2.21 & -1.24 & & 54.81 & 4.22 & $* * *$ & -0.88 & -0.17 & & 102.66 & 2.88 & $* * *$ \\
\hline Instrument for change in sales price & --- & --- & & -0.35 & -1.10 & & --- & --- & & -3.12 & -2.38 & ** \\
\hline F-statistic & & 255.39 & $* * *$ & & 22.24 & $* * *$ & & 17.16 & $* * *$ & & 11.31 & $* * *$ \\
\hline Adj $R^{2}$ & & 0.50 & & & 0.06 & & & 0.37 & & & 0.55 & \\
\hline
\end{tabular}

Turning to the variables of interest, homes that are initially farther from big box stores generally have higher prices, an effect which is largest and most significant for Best Buy locations, but is in fact statistically insignificant for Wal-Mart. Interestingly, homes that are closer to Target locations command a (statistically insignificant) higher price. This could, of course, be due to the endogenous choice of location by each store, but the arrival of a new Wal-Mart raises the price of nearby homes by almost one percent compared to peer homes outside of a two-mile radius of the arrival. Best Buy has a similar positive effect of close to one percent, compared to the unaffected control group of homes. Further, the interaction term between distance and arrival reflects the fact that distance from a newly arrived Wal-Mart is very important for affected homes, with price appreciating with distance from the Wal-Mart (at the rate of roughly 0.6 percent per mile). This seems to indicate that the importance of the pollution externalities is most starkly impacting homes near a Wal-Mart. Interestingly, Best Buy has the opposite effect, with homes closest to the new arrival least affected by the store opening. In contrast, this seems to indicate that the positive convenience effect outweighs the importance of the negative pollution externalities in the case of a Best Buy store.

We also find that the number of days between the opening of the newest big-box store and the property's sales date (dayssince) is positively correlated with higher sales prices. We believe this captures the "news effect" of an additional big-box store: property values adjust when the store goes in, and over time the effect only becomes more positive for price. This suggests that homeowners should wait to sell the property rather than selling immediately upon the opening of a new store.

Results are largely paralleled with the dependent variable measuring days on market. Larger homes sell more slowly, older homes sell more quickly, and certain years obviously experienced tighter market conditions than others. The ar- 
rival of a Wal-Mart shows no significant effect on the expected number of days on the market, while the arrival of a Best Buy reduced the expected time on market by slightly more than three days. All of these effects are lessened among the subset of homes that changed hands four or more times during the sample period, though many of the effects are statistically insignificant.

This result corresponds to the intuition surrounding the convenience-nuisance duality that accompanies a big-box store. Close proximity to the store ensures convenient access, but also provides for greater traffic, noise and light pollution. Greater distance from the store location diminishes the convenience aspect, while also reducing the pollution nuisance. Over time, it appears that citizens acclimate to the externalities, and increasingly appreciate the convenience aspects more than they detest the pollution nuisance.

To put the coefficient values in perspective, we must put the realtor's mantra of "location, location, location" into perspective against the popular maxim that "timing is everything". While location relative to a big box store might affect sales price by one or two percent, mistiming the sale of a property by one year at any point in our sample could easily lead to price differentials of that much or more. In short, the effect of a big box store, any big box store, on repeated sales value, appears to be well within the margin of error accepted by realtors when listing a home.

\section{Conclusions}

Using a large dataset of repeated residential property sales, this paper evaluates the claim that the arrival by a big-box store (the most notable example being Wal-Mart) reduces adjacent home values. We control as carefully as possible for changes in the macroeconomic climate and neighborhood effects, finding virtually no evidence to support the claim of reduced property values. Indeed, the Wal-Mart effects look only slightly worse than Best Buy effects (and only if held in isolation from properties which experienced a new arrival of neither one). Moreover, the effects improve over time and appear to amount to no more financial significance than a measurement error by a listing realtor when offering a home for sale. Further, there seems to be no statistical relationship between the presence of a store, the arrival of a store (with the exception of Best Buy), or the distance from a store, and the number of days that a property remains on the market before sale.

Is Wal-Mart a bad neighbor then? Quite the opposite appears to be true. This work's quantitative evidence shows that Wal-Mart's effect is actually positive for average residential property values, and becomes more so with the passage of time. Previous studies that asserted otherwise appear to have been contaminated by bias, or by the innate correlation of location choices by each variety of store with different price ranges and ages of neighborhoods.

Further work could of course extend this analysis to other areas, or address level effects rather than changes (e.g. does Wal-Mart choose to enter different 
neighborhoods because of prevailing property values?). Meanwhile, we hope that this work puts to rest a commonly held misconception about big-box stores and their impact on home values.

\section{Conflicts of Interest}

The authors declare no conflicts of interest regarding the publication of this paper.

\section{References}

[1] Fox, K. (2005) Wal-Mart: The High Cost of Low Price: Review. TV Guide Online. http://movies.tvguide.com/wal-mart-high/review/195873

[2] Anderson, D. (2013) Residents Rally against WalMart's Plans for New Store in Bel Air. Baltimore Sun.

http://www.baltimoresun.com/news/maryland/harford/abingdon/ph-ag-walmart-pr otest-0410-20130406-story.html.

[3] Ingram, P., Yue, L.Q. and Rao, H. (2010) Trouble in Store: Probes, Protests and Store Openings by Wal-Mart, 1998-2007. American Journal of Sociology, 116, 53-92. https://doi.org/10.1086/653596

[4] Paruchuri, S., Baum, J.A.C. and Potere, D. (2009) The Wal-Mart Effect: Wave of Destruction or Creative Destruction? Economic Geography, 85, No. 2. https://doi.org/10.1111/j.1944-8287.2009.01023.x

[5] Artz, G. and Stone, K.E. (2006) Analyzing the Impact of Wal-Mart Supercenters on Local Food Stores Sales. American Journal of Agricultural Economics, 88, 1296-1303. https://doi.org/10.1111/j.1467-8276.2006.00948.x

[6] Davis, J., Merriman, D., Samayoa, L. and Flanagan, B. (2009) The Impact of an Urban Wal-Mart Store on Area Businesses: An Evaluation of One Chicago Neighborhood's Experience. Working Paper, Loyola University Center for Urban Research and Learning, Chicago.

[7] Goetz, S.J. and Rupasingha, A. (2006) Wal-Mart and Social Capital. American Journal of Agricultural Economics, 88, 1304-1310. https://doi.org/10.1111/j.1467-8276.2006.00949.x

[8] Basker, E. (2006) Job Creation or Destruction? Labor Market Effects of Wal-Mart Expansion. Review of Economics and Statistics, 87, 174-183. https://doi.org/10.1162/0034653053327568

[9] Hicks, M.J. (2007) Job Turnover and Wages in the Retail Sector: The Influence of Wal-Mart. Journal of Private Enterprise, 22,137-160.

[10] Hausman, J. and Leibtag, E. (2005) Consumer Benefits from Increased Competition in Shopping Outlets: Measuring the Effect of Wal-Mart. Working Paper 11809, National Bureau of Economic Research. Cambridge.

[11] Neumark, D., Zhang, J.F. and Ciccarella, S. (2007) The Effects of Wal-Mart on Local Labor Markets. Journal of Urban Economics, 63, 405-430. https://doi.org/10.1016/j.jue.2007.07.004

[12] Goetz, S.J. and Swaminathan, H. (2006) Wal-Mart and Count-Wide Poverty. Social Science Quarterly, 87, 211-226. https://doi.org/10.1111/j.1540-6237.2006.00377.x

[13] Vandegrift, D. and Lahr, M. (2011) Open Space, House Prices and the Tax Base. Annals of Regional Science, 46, 83-100. https://doi.org/10.1007/s00168-009-0336-1 
[14] Loyer, J. (2010) The Effect of Wal-Mart on Residential and Commercial Property Values: Evidence from New Jersey. Dissertation, The College of New Jersey, Ewing.

[15] Corlija, M., Simon, E. and Finke, M.S. (2006) Longitudinal Analysis of Big Box Store Construction on Nearby Home Values. Consumer Interest Annual, 52, 187-197.

[16] Brigham, E.F. (1965) The Determinants of Residential Land Values. Land Economics, 41, 325-334. https://doi.org/10.2307/3144665

[17] Lafferty, R.N. and French III, H.E. (1978) Community Environment and the Market Value of Single-Family Homes: The Effect of the Dispersion of Land Uses. Journal of Law \& Economics, 21, 381-394. https://doi.org/10.1086/466926

[18] Van Cao, T. and Cory, D.C. (1982) Mixed Land Uses, Land-Use Externalities, and Residential Property Values: A Re-Evaluation. Annals of Regional Science, 16, 1-24. https://doi.org/10.1007/BF01287403

[19] Cervero, R. and Duncan, M. (2004) Neighbourhood Composition and Residential Land Prices: Does Exclusion Raise or Lower Values? Urban Studies, 41, 299-315. https://doi.org/10.1080/0042098032000165262

[20] Spikowski, W.M. (2006) The Complete Guide to Zoning: How Real Estate Owners and Developers Can Create and Preserve Property Value. Journal of the American Planning Association, 72, 376-377.

[21] Haughwout, A., Orr, J. and Bedol, D. (2008) The Price of Land in the New York Metropolitan Area. Current Issues in Economics \& Finance, 14, 2-7.

[22] Friedman, J.P. (1975) Valuation of Encumbered Acreage. Appraisal Journal, 43, 410-420.

[23] Brueckner, J.K. and Colwell, P.F. (1983) A Spatial Model of Housing Attributes: Theory and Evidence. Land Economics, 59, 58-69. https://doi.org/10.2307/3145876

[24] Blamire, P.A. and Barnsley, M.J. (1996) Inferring Urban Land Use from an Analysis of the Spatial and Morphological Characteristics of Discrete Scene Objects. Proceedings of the 22nd Annual Conference of the Remote Sensing Society, Durham, 11-14 September 1996, 529-536.

[25] Clapp, J.M. (2003) A Semiparametric Method for Valuing Residential Locations: Application to Automated Valuation. Journal of Real Estate Finance \& Economics, 27, 303-320. https://doi.org/10.1023/A:1025838007297

[26] Sirmans, G., MacDonald, L., Macpherson, D. and Zietz, E. (2006) The Value of Housing Characteristics: A Meta Analysis. Journal of Real Estate Finance \& Economics, 33, 215-240. https://doi.org/10.1007/s11146-006-9983-5

[27] Garrod, G. and Willis, K.G. (1992) Valuing Goods' Characteristics: An Application of the Hedonic Price Method to Environmental Attributes. Journal of Environmental Management, 34, 59-76. https://doi.org/10.1016/S0301-4797(05)80110-0

[28] Clapp, J.M. and Giaccotto, C. (1992) Estimating Price Indices for Residential Property: A Comparison of Repeat Sales and Assessed Value Methods. Journal of the American Statistical Association, 87, 300-306. https://doi.org/10.1080/01621459.1992.10475209

[29] Cypher, M.L. and Hansz, J.A. (2003) Does Assessed Value Influence Market Value Judgments? Journal of Property Research, 20, 305-308. https://doi.org/10.1080/0959991042000182001

[30] Hess, D.B. and Almeida, T.M. (2007) Impact of Proximity to Light Rail Rapid Transit on Station-Area Property Values in Buffalo, New York. Urban Studies, 44, 1041-1068. https://doi.org/10.1080/00420980701256005 
[31] Byrne, P.F. (2006) Determinants of Property Value Growth for Tax Increment Financing Districts. Economic Development Quarterly, 20, 317-329. https://doi.org/10.1177/0891242406291540

[32] Genesove, D. and Mayer, C.J. (1997) Equity and Time to Sale in the Real Estate Market. American Economic Review, 87, 255-269.

[33] Anglin, P.M., Rutherford, R. and Springer, T.M. (2003) The Trade-Off between the Selling Price of Residential Properties and Time-on-the-Market: The Impact of Price Setting. Journal of Real Estate Finance and Economics, 26, 95-111. https://doi.org/10.1023/A:1021526332732

[34] Mok, D.K. (2003) Disentangling the Market Price: Seller's Reservation Price, Buyer's Offer Price, and the Listing's Days on Market. Working Paper, Department of Geography, McGill University, Montreal.

[35] Hoeberichts, M., van Rooij, M. and Siegmann, A. (2008) Market Thinness, List Price Revisions and Time to Sell: Evidence from a Large-Scale Housing Dataset. Working Paper No. 176/2008, De Nederlandsche Bank NV, Amsterdam.

[36] Hendon, W.S. (1971) The Park as a Determinant of Property Values. American Journal of Economics \& Sociology, 30, 289-300. https://doi.org/10.1111/j.1536-7150.1971.tb03232.x

[37] Jackson, T.O. (2009) When Good Things Happen to Bad Properties. Appraisal Journal, 77, 112-116.

[38] Poon, L.C.L. (1978) Railway Externalities and Residential Property Prices. Land Economics, 54, 218-227. https://doi.org/10.2307/3146235

[39] Nelson, J.P. (1982) Highway Noise and Property Values: A Survey of Recent Evidence. Journal of Transport Economics and Policy, 16, 117-138.

[40] Pennington, G., Topham, N. and Ward, R. (1988) Aircraft Noise and Residential Property Values Adjacent to Manchester International Airport. Journal of Transport Economics and Policy, 24, 49-59.

[41] Boyle, M.A. and Kiel, K.A. (2001) A Survey of House Price Hedonic Studies of the Impact of Environmental Externalities. Journal of Real Estate Literature, 9, 117-144.

[42] Kiel, K.A. and Williams, M. (2005) The Impact of Superfund Sites on Local Property Values: Are All Sites the Same? College of the Holy Cross, Department of Economics, Faculty Research Series, Working Paper No. 05-05.

[43] Kiel, K.A. (2006) Environmental Contamination and House Values. College of the Holy Cross, Department of Economics, Faculty Research Series, Working Paper No. 06-01.

[44] Gayner, T. and Viscusi, W.K. (2002) Housing Price Responses to Newspaper Publicity of Hazardous Waste Sites. Resource and Energy Economics, 24, 33-51. https://doi.org/10.1016/S0928-7655(01)00047-1

[45] Tu, C.C. (2005) How Does a New Sports Stadium Affect Housing Values? The Case of FedEx Field. Land Economics, 81, 379-395. https://doi.org/10.3368/le.81.3.379

[46] Case, K.E. and Mayer, C.J. (1996) Housing Price Dynamics within a Metropolitan Area. Regional Science and Urban Economics, 26, 387-407. https://doi.org/10.1016/0166-0462(95)02121-3

[47] Gayner, T., Hamilton, J.T. and Viscusi, W.K. (2002) The Market Value of Reducing Cancer Risk: Hedonic Housing Prices with Changing Information. Southern Economic Journal, 69, 266-289. https://doi.org/10.2307/1061672

[48] Voicu, I. and Been, V. (2008) The Effect of Community Gardens on Neighboring Property Values. Real Estate Economics, 36, 241-283. 
https://doi.org/10.1111/j.1540-6229.2008.00213.x

[49] Wachter, S.M. and Wong, G. (2008) What Is a Tree Worth? Green-City Strategies, Signaling and Housing Prices. Real Estate Economics, 36, 213-239. https://doi.org/10.1111/j.1540-6229.2008.00212.x

[50] Turnbull, G. and Dombrow, J. (2005) Identifying Agent-Specific Influences in the Brokerage Process. National Center for Real Estate Research Working Paper.

[51] Knight, J.R., Sirmans, C.F. and Turnbull, G.K. (1994) List Price Signaling and Buyer Behavior in the Housing Market. Journal of Real Estate Finance and Economics, 9, 177-192. https://doi.org/10.1007/BF01099271

[52] Samaha, S.A. and Kamakura, W.A. (2008) Assessing the Market Value of Real Estate Property with a Geographically Weighted Stochastic Frontier Model. Real Estate Economics, 36, 717-751. https://doi.org/10.1111/j.1540-6229.2008.00228.x

[53] Graddy, K., Hamilton, J. and Pownall, R. (2011) Repeat-Sales Indexes: Estimation without Assuming That Errors in Asset Returns Are Independently Distributed. Real Estate Economics, 40, 131-166. 